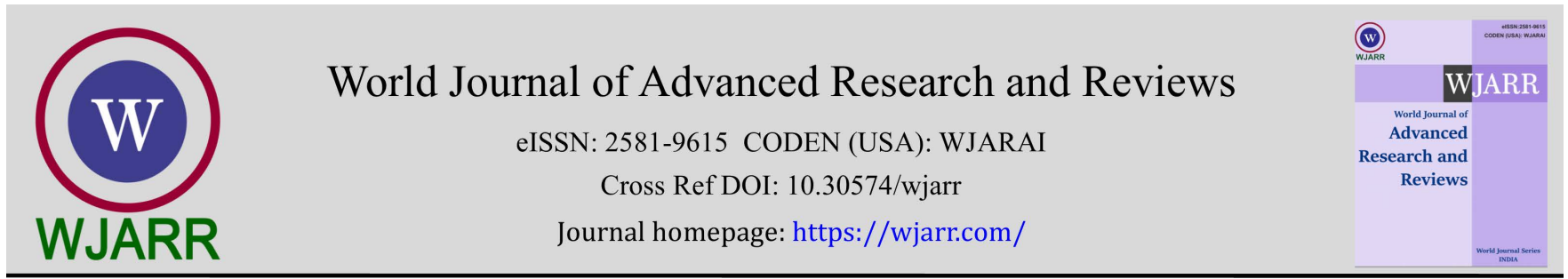

(RESEARCH ARTicle)

\title{
Effects of school ownership on problem-solving abilities in algebra among senior secondary school students in Rivers State
}

\author{
Jessey I. Obunge *, Macson J. Ahiakwo, Telima Adolphus and Muvoke D. Omeodu. \\ Department of Science Education, Faculty of Education, Rivers State University Port- Harcourt, Nigeria.
}

World Journal of Advanced Research and Reviews, 2022, 13(01), 398-403

Publication history: Received on 07 December 2021; revised on 10 January 2022; accepted on 12 January 2022

Article DOI: https://doi.org/10.30574/wjarr.2022.13.1.0028

\begin{abstract}
The study investigated the effects of school ownership on problem solving abilities in algebra among senior secondary school students, in Rivers State, Nigeria. Ex-post facto design was used in this study. The population was all senior secondary school students in Rivers State. Convenience and purposive sampling technique was employed in this study. 390 senior secondary school students participated in the study. Nine senior secondary schools were selected by purposive sampling for the study in two local government areas. The instrument used was Algebraic Problem Solving Test questions collated by the researchers from different past West African School Certificate Examinations. The reliability of the test was determined to be 0.72 using Pearson product moment correlation formula. Three research questions were answered using simple mean. One hypothesis was raised to guide the study, at 0.05 significant level using t-test. The results of the analyses showed that: school ownership had significant effect on the problem solving ability in algebra of senior secondary school students, about $86 \%$ of the students in the private schools scored below $50 \%$ in the test, about $96 \%$ of the students in the public schools scored $49 \%$ and below, the students in the private schools outperformed their counterparts in the public schools although generally, the performance of students in both public and private schools was quite low. Based on the findings, recommendations were made.
\end{abstract}

Keywords: School ownership; Algebra; Problem-solving Ability; private and public schools

\section{Introduction}

Problem solving is an essential aspect of human activity, thus the major part of human thinking is consciously aimed towards problem-solving [1]. Generally problem means a situation that is harmful and not welcome that needs to be addressed and resolved. However, one of the ways humans provide solution to problems in life is through the application of mathematical procedures. According to [2] one of the purposes of studying mathematics is to solve problems, thus it involves the ability to understand problems, prepares mathematical models, completing models, interpreting the models and to prepare students to solve problems regularly. As noted by [3], mathematics is a problemsolving game in which there are several procedural mathematical problems focusing on algorithmic process, seeking for correct answer in mathematics text. Those who consider it as a game enjoy the challenges of developing new mathematics and solving previously unsolved problems in the various branches of mathematics. According to [4], problem solving is said to be one of the root causes of poor academic performance in science related disciplines. This occur as a result of students' inability and unwillingness to acquire the basic knowledge involved in solving problems, they rather prefer memorizing solutions given by teachers in line with outdated methods of teaching in spite of the fact that problem solving spans across all spheres of life. As noted by [5] problem solving ability is a basic skill needed by individuals and is virtually applied in all areas of human endeavor. Specifically, mathematics is regarded as a universal branch of science that is highly important in the society, as its requirement is seen as a prerequisite to the study of many science oriented courses, notably, in engineering, science, business management, medicine, agriculture, computer

\footnotetext{
${ }^{*}$ Corresponding author: Obunge Jessey I

Department of science education faculty of education rivers state university port harcourt, rivers state, nigeria. 
sciences among others. Various techniques have been adopted in finding solutions to problems through mathematical operation. The twentieth centuries and beyond have witnessed increasing difficulties and complexities that required high problem-solving skills at the workplace as well as in the society and as such, makes mathematical literacy becomes one of the components required to develop the $21^{\text {st }}$ century skills [6]. [7] states that mathematics helps to provide students the ability to work harmoniously and as well, prepares them to think creatively, analytically, logically and critically. As noted by [8], mathematics is the pillar of national development, as the level of expertise acquired in mathematics, to an extent determines the level of scientific and technological development of nations. Mathematics is applied in every occupation and activity in human lives. It is crucial in today's business management, as organizations use it to complete business operations efficiently in areas such as accounting, marketing, sales forecast, inventory management among others. Mathematical knowledge is also applied in Arts, as Pythagoras the most notable mathematician acknowledged, numerical reasoning in harmonizing music [9].

Most notably, mathematics has contributed enormously in the areas of Science and Technology as it is viewed as the Knowledge of Science, Technology and Engineering [9]. It is one of the critical components, in addition to Science, Technology and Engineering which is known to be 'STEM' areas as acknowledged by developed nations as tool for prosperity. Knowledge of mathematics has been applied in Biotechnology, Advanced semiconductor device, Digital image technology, Nano technology, Artificial satellites, Agriculture, Medical sciences and so on as it is used in manufacturing devices, DNA sequencing and gene technology to name a few. Mathematics solves problem through logic, as the rule of logic allows philosophers make true and logical deduction about the world. Through general rules, mathematics proffers solutions to numerous problems simultaneously as well as the application of these rules to other problems [10].

Though in Nigeria and other parts of the world, school ownership is said to have played a dominant role in education, continual poor performance of students in mathematics have been attributed to several factors. Most notable among them include: overpopulated mathematics classrooms, negative attitude exhibited towards mathematics study, inadequate teaching facilities, undue emphasis laid on the coverage of mathematics course content at the detriment of students' meaningful understanding of the basic concepts. Some studies have revealed that private school students have a higher problem-solving ability than the students in public schools in mathematics [11]. Could this report be the same in all cases, that students in private schools outperform their counterparts in public schools in problem-solving in mathematics? This is why this study seeks to examine the effect of school ownership on problem-solving abilities in mathematics among senior secondary school students in Rivers State.

\subsection{Purpose of the Study}

The purpose of the study was to:

- investigate how senior secondary students in private schools solve problems in algebra.

- investigate how senior secondary students in public schools solve problems in algebra.

- $\quad$ assess the effect of school ownership (private and public schools) on the problem-solving abilities in algebra among senior secondary students in Rivers State.

\subsection{Research Question}

The following questions were answered in the study:

- How do senior secondary school students in private schools solve algebraic problems?

- How do senior secondary school students in public schools solve algebraic problems?

- What is the effect of private and public schools on problem-solving abilities in algebra among senior secondary students in Rivers State?

\subsection{Hypothesis}

\subsection{1. $\mathrm{HO1}$}

There is no significant difference in the problem-solving abilities in algebra among senior secondary students in private and public schools in Rivers State. 


\subsubsection{Methodology}

In order to achieve the objectives of the study, ex-post factor design was adopted, it was used because the variables of the study had already occurred and were not manipulated by the researchers. The target population of the study was all 145,894 senior secondary school students in Rivers State Nigeria.

Source of data: (Post Primary Schools Board, Rivers State Ministry of Education 2020/2021 schools registration).

This study adopted convenience and purposive sampling technique. The study was carried out in Port-Harcourt and Akuku-Toru local government areas in Rivers State, selected by convenience sampling. Nine senior secondary schools (six in Port-Harcourt local government area and three in Akuku-Toru local government area) were purposively selected to participate in this study. The study involved three private and six public schools from both local government areas. Intact class method was employed to administer the questions in the different schools. A sample of 390 senior secondary school students obtained through Taro Yamane formula, participated in this study. Senior secondary school III class was purposively selected for the study, this is because the researchers considered that at this level, the students would have been taught sufficient algebraic contents. The researchers also confirmed this status from the mathematics teachers in the schools that participated. The instrument used in this study was five algebraic word problems collated by the researchers from past West African School Certificate Examinations. The instrument was face and content validated by experts in the Faculty of Education in Rivers State University and a professor of mathematics education in Ignitius Ajuru University, Rivers State. Comments and suggestions from the validators were used to further improve the instrument. It was validated using the blue print table of specification. One of the researchers administered the instrument personally with the support of some teachers in the schools that participated in the study. The algebraic questions used as the instrument, have the components of Polya's suggested four stages of problem solving model. The answers were graded accordingly. Questions 1 and 5 correctly answered were graded 15 marks each, questions 2, 3 and 4 correctly answered were graded 10 marks each so the maximum score for the five questions was 60 marks, which was converted to percentage. The same questions were pre-tested, using test-retest method which involved 20 students from one senior secondary school in Obio-Akpor local government area of Rivers State, which is outside the study area. The questions were administered to the students twice in two weeks interval. The two sets of scores from these students were collated to obtain reliability co-efficient of 0.72 with the use of Pearson's Product Moment Co-relation formula. Test scores of $50 \%$ and above in this study were considered as good performance and classified as high problem-solving ability, while scores of $49 \%$ and below were considered as poor performance and classified as low problem solving ability. The research questions were answered by simple mean while the null hypothesis was analyzed at 0.05 level of significance using t-test. The decision rule was to accept the null hypothesis if $p$-value is greater than the significant level of 0.05 and to reject the null hypothesis if p-value is less than 0.05 , level of significance.

\section{Results}

\subsection{Research Question 1}

How do senior secondary students in private schools solve algebraic problems?

The analysis on table 1 below gives the answer to research question 1

Table 1 Private Schools Students' Performance

\begin{tabular}{|l|l|l|l|l|}
\hline & SCORES & $\mathbf{N}$ & $\mathbf{\%}$ & MEAN \% \\
\hline High Ability & $\geq 50 \%$ & 11 & 14 & 59.00 \\
\hline Low Ability & $\leq 49 \%$ & 70 & 86 & 14.84 \\
\hline Total & & 81 & 100 & \\
\hline
\end{tabular}

Table 1 revealed that out of 81 students in the private schools, only11 students representing about $14 \%$ of the total number of students from the private schools, scored up to $50 \%$ and above in the algebraic test with a mean score of about $59 \%$, while 70 students representing about $86 \%$ of the total number of students from the private schools, scored below $50 \%$ in the test, with a mean score of about $15 \%$. 


\subsection{Research Question 2}

How do senior secondary students in public schools solve algebraic problems?

The analysis on table 2 answers research question 2 .

Table 2 Public Schools Students' Performance

\begin{tabular}{|l|l|l|l|l|}
\hline \multicolumn{2}{|l|}{ SCORES } & N & \% & MEAN \\
\hline High Ability & $\geq 50 \%$ & 12 & 4 & 56.167 \\
\hline Low Ability & $\leq 49 \%$ & 297 & 96 & 5.518 \\
\hline Total & & 309 & 100 & \\
\hline
\end{tabular}

Table 2 showed that only 12 students out of 309 from the public schools representing about $4 \%$ of the total number of students from the public schools that participated in the study scored 50\% and above with a mean score of about $56 \%$, while 297 students out of 309 representing about $96 \%$ of the total number of students from the public schools scored below $50 \%$ with a mean score of about $6 \%$.

\subsection{Research Question 3}

How do senior secondary students in private and public schools solve algebraic problems?

Analysis on table 3 answers research question 3.

Table 3 Comparison of Mean scores by school ownership

\begin{tabular}{|l|l|l|l|}
\hline & $\begin{array}{l}\text { Public } \\
(\mathbf{N = 3 0 9 )}\end{array}$ & $\begin{array}{l}\text { Private } \\
\mathbf{( N = 8 1 )}\end{array}$ & Mean Difference \\
\hline Mean score & 8.50 & 18.20 & 9.70 \\
\hline Std. Error Mean & 0.40 & 2.40 & \\
\hline
\end{tabular}

Table 3 showed that the number of students in private schools in this study is 81 with a mean score of $18.20 \%$ and the number of students in public schools is 309 with a mean score of $8.50 \%$. The students in the private schools have a remarkable higher problem solving abilities in algebra compared to those in the public schools with a mean difference of 9.70 as revealed in this study.

\subsection{Null Hypothesis}

There is no significant difference in the problem solving abilities in algebra among senior secondary students in public and private schools.

Table 4 T-test analysis of Mean scores by school ownership

\begin{tabular}{|l|l|l|l|l|l|l|l|l|}
\hline Owner-ship & $\mathbf{N}$ & $\bar{x}$ & $\begin{array}{l}\text { Std. } \\
\text { Deviation }\end{array}$ & $\begin{array}{l}\text { Std. } \\
\text { Error Mean }\end{array}$ & df & t-cal & p-value & Decision \\
\hline Private & 81 & 18.20 & 21.838 & 2.400 & 388 & 8.12 & 0.0001 & Rejected \\
\hline Public & 309 & 8.50 & 9.057 & 0.400 & & & & \\
\hline \multicolumn{7}{|c|}{$\mathrm{t}(388)=8.12, \mathrm{P}<0.05$ therefore the null hypothesis is rejected. }
\end{tabular}


Table 4 showed p-value to be 0.0001 which is less than the significant level of 0.05 . Therefore, there is statistically significant difference between the mean scores of students in the private and public schools in favour of students in the private schools. Hence, the null hypothesis is rejected.

\section{Discussion of Findings}

The study was carried out to investigate effects of school ownership on problem-solving abilities in algebra among senior secondary school students in Rivers State, Nigeria. In order to achieve this, three research questions were answered.

Research question one (1) sought to investigate how senior secondary students in private schools solve algebraic problems. The study showed that out of 81 students in the private schools that participated in the study, only11 students which represents $14 \%$ of the total number of students from the private schools, scored up to $50 \%$ and above in the algebraic test with a mean score of about 59\%. While 70 students representing $86 \%$ of the total number of students from the private schools that participated in the study, scored below 50\% in the test, with a mean score of about $15 \%$ as in table 1 . This indicates a low problem-solving ability of majority of the students in the private schools.

Research question two (2) sought to investigate how senior secondary students in public schools solve algebraic problems. Table 2 showed that only 12 students out of 309 from the public schools that participated in the study, representing about $4 \%$ of the total number of students from the public schools scored $50 \%$ and above with a mean score of 56\%, while 297 students out of 309 from the public schools that participated, representing about $96 \%$ of the total number of students from the public schools scored below $50 \%$ with a mean scored of about $6 \%$. This revealed a very low problem-solving ability of majority of the students in the public schools. Research question three (3) sought to investigate the effects of school ownership on the problem-solving abilities of senior secondary school students in algebra. Table 3 showed that the number of students that participated in this study from private schools was 81 with a mean score of $18.20 \%$ and the number of students that participated from the public schools is 309 with a mean score of $8.50 \%$. The students in the private schools have a remarkable higher problem solving abilities in algebra compared to those in the public schools with a mean difference of 9.70 as revealed in this study.

The result obtained from the t-test revealed that there is a significant difference between the means of the two groups in favour of the students in private schools. Students in the private schools had higher problem-solving abilities than their counterparts in the public schools, although the general performance of students in both the private and public schools is very poor indicating a general low problem-solving ability of students in algebra . This result is in line with the result of [11] that did a study on performance of students on the Ghanaian junior high school certificate examination in Effutu Municipality Junior High Schools in central region, Ghana. Their results revealed that in that municipality, students in the private schools outperformed their counterparts in the public schools. The results further found out that about $77 \%$ of the students in private schools achieved proficiency while only about $23 \%$ from the public schools achieved proficiency. The result of this study is also in consonance with the results of, [12] who studied problems in algebra: Nigerian junior secondary school students' experience, and worked with a sample of one hundred and eighty one (181) students from two public and two private schools in Lagos state. The instrument for data collection was algebraic problems. His findings did not show separate results for the public and private schools he worked with, it rather showed that only about $10 \%$ of the whole students involved answered the questions they were given correctly. Based on the poor performance, he suggested more focused approaches in the teaching of algebra with special attention to word problems in Nigerian secondary schools especially at the junior school level to lay a good and strong foundation in mathematics.

\section{Conclusion}

The following conclusions were made based on the findings from the study: about $94 \%$ of the students that participated in the study, lack the ability to solve algebraic problems systematically. However, it is evident that, the mean score of the students from private schools was higher than that of their counterparts in the public schools. The mean score difference between the two school types was 9.70 and this is statistically significant in favour of the students in the private schools. School ownership therefore has significant effect on the problem solving abilities in algebra among senior secondary school students in this study.

\section{Recommendations}

The following recommendations were made based on the findings from the study: problem solving models like Polya's should be part of mathematics curriculum in our secondary schools and be adhered to since problem solving is the 
essence of mathematics. Stake holders in the educational system especially curriculum developers and mathematics teachers should focus more on the teaching of algebra with special attention to word problems in Nigerian secondary schools especially at the junior secondary level to lay a strong and good foundation in mathematics. Developing students' ability to solve problems is the integral part of mathematics learning at all levels and in all school types, therefore all students in both public and private schools, should be encouraged to take problem-solving seriously, in order to improve their abilities in solving problems systematically, as this is required in all aspects of life.

\section{Compliance with ethical standards}

\section{Acknowledgments}

We acknowledge the validators, heads of schools and students that participated in this study and all who assisted in one way or the other and made this study a success.

\section{Disclosure of conflict of interest}

There is no conflict of interest to be declared

\section{Statement of informed consent}

Informed consent was obtained from heads of schools involved and students that participated in the study.

\section{References}

[1] Alacaci C, \& Dogruel M. Solving a stability problem by Polya's four steps. International Journal of Electronics Mechanical and Mechatronics Engineering. 2012; 1(1): 19-28.

[2] Napaphun V. Relational Thinking: Learning Arithmetic in order To Promote Algebraic Thinking. Journal of Science and Mathematics Education in Southeast Asia 2012; 35(2): 84-101

[3] Pant B, \& Luitel BC. Beliefs about the nature of mathematics and its pedagogical influence. Presented on 13th International conference on mathematical evaluation, Humburg, 24-31, July, 2016. cognitive assessments and teacher ratings. American Educational Research Journal. 2016; 48(1): 268-302.

[4] Elizabeth J, Abdul HA, \& Nornazira S. Attitude of students towards solving problems in Algebra: A review of Nigerian secondary schools. Journal of Research \& Method in Education. 2018; 8(1): 26-31.

[5] Kaya D, Izgiol D, \& Kesan C. The investigation of elementary mathematics teacher candidates' problem solving skills according to various variables. International Electronic Journal of Elementary Education. 2014; 6(2): 295314 .

[6] Julie H, Sanjaya F, \& Anggoro Y. The students' ability in mathematical literacy for uncertainty problems on the PISA adaptation text AIP Conference Proceedings (Yogyakarta: Universitas Negeri Yogyakarta). 2017.

[7] Narad, A., \& Abdullah, B. The Academic Performance of Senior Secondary School Students: Influence of Parental Encouragement and School Environment. Rupkatha Journal on Interdisciplinary Studies in Humanities. 2016; 8(2): 12-19

[8] Jayanti R, \& Rahayuningsih S. High Order Thinking Skills (HOTS) of Students in Solving Group Problem Based on Gender. Al-Jabar Journal Pendidikan Matematica. 2019; 10(2): 243-250.

[9] Jayanthi R. Mathematics in society development: A study. Iconic Research and Engineering Journals. 2016; 3(3): 59-64.

[10] AMS, Grad Blog. The role of generalization in the advanced mathematical thinking. Journal of the American Mathematical Society. 2016.

[11] Mills, E.D \& Mereku, D.K. Students Performance on the Ghanaian Junior High School. African Journal of Educational Studies in Mathematics and Sciences. 2016; 12(1): 25-34

[12] Ogunsaya, E. A., Akintude, S.O., \& Olatoye, R. A. Relationship Between Creativity and Academic Achievement of Business Administration Students in South Western Polytechnics, Nigeria. African Research Review 2015; 4(3): 134-149 